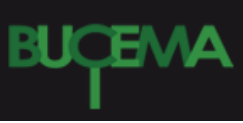

Bulletin du centre d'études médiévales d'Auxerre | BUCEMA

Hors-série $n^{\circ} 7 \mid 2013$

Les nouveaux horizons de l'ecclésiologie : du discours clérical à la science du social

The synodial practices of the Council of Constance (1414-1418): Between symbol and trace

Sebastián Provvidente

(2) OpenEdition

Journals

Electronic version

URL: https://journals.openedition.org/cem/12784

DOI: $10.4000 / \mathrm{cem} .12784$

ISSN: 1954-3093

Publisher

Centre d'études médiévales Saint-Germain d'Auxerre

Electronic reference

Sebastián Provvidente, "The synodial practices of the Council of Constance (1414-1418): Between symbol and trace", Bulletin du centre d'études médiévales d'Auxerre | BUCEMA [Online], Hors-série n 7 | 2013, Online since 21 March 2013, connection on 02 March 2023. URL: http:// journals.openedition.org/cem/12784; DOI: https://doi.org/10.4000/cem.12784

This text was automatically generated on 2 March 2023.

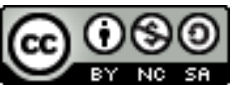

Creative Commons - Attribution-NonCommercial-ShareAlike 4.0 International - CC BY-NC-SA 4.0 https://creativecommons.org/licenses/by-nc-sa/4.0/ 


\title{
The synodial practices of the Council of Constance (1414-1418): Between symbol and trace
}

\author{
Sebastián Provvidente
}

1 The decree Haec Sancta approved by the Council of Constance at its $5^{\text {th }}$ Session ( $6^{\text {th }}$ April 1415) helped the Council fathers to put an end to the scandalous schism which since 1378 had divided the Latin Church between rival lines of claimants to the papal office. It did so by claiming and exercising an authority superior to that of the Pope in certain circumstances. However, the interpretation of this decree has been a source of disagreement between historians, theologians and canonists. It is not our intention to propose in this presentation a new interpretation, but only to point out that since the Vatican I Council the origin of these divergent perspectives has usually been rooted in $a$ priori theological or canonical attitudes or criteria. We think that the proper interpretation of this text can only be made through a careful reconstruction of the immediate context in which the decree was conceived. Finally, at the end of this presentation we will try to suggest that the judicial practices (trials and depositions) at the Council of Constance, though usually disregarded, are a very helpful element to reconstruct the true meaning of the decree Haec Sancta.

2 When John XXIII, the Pope who had convoked the Council of Constance, realized that he could not manipulate it through the numerical majority of Italian religious leaders, he decided to leave the assembly and escaped to Schaffhausen where he started to work for the dissolution of the assembly. The response to this event was the approval of the Haec sancta. The decree tried to answer the following questions: was it possible to celebrate a Council without the papal support or even against his will? If it was possible, what was the origin of the conciliar authority? During the $3^{\text {rd }}$ session celebrated on $26^{\text {th }}$ March of 1415 the Council decided to fight against any intention of dissolution and restated its decision of resolving the issues of causa unionis, fidei et reformationis ${ }^{1}$. The next session took place three days later and the cardinal Francesco Zabarella was in charge of reading a text that had been written with the scope of 
justifying the conciliar authority. However, when the cardinal Zabarella proceeded to do it, he omitted an important fragment affirming the power of the Council to enact without papal support the reform in capite et membris ${ }^{2}$. After some new negotiations, the sentence was finally included in the decree approved at the $5^{\text {th }}$ session affirming that the Council held its power immediately from Christ ${ }^{3}$. From this moment onwards the text of the decree has been a major object of controversy ${ }^{4}$ (For the text of the Haec sancta see Appendix).

3 As we mentioned before, our first aim here will be to show how theological and canonical criteria influenced and conditioned the hermeneutical activities since the times of the Vatican I (1870). The affirmation of papal infallibility and primacy proclaimed by the Vatican Council I turned the Council of Constance and in particular the text of the Haec sancta into a highly conflictive issue that should be forgotten instead of studied ${ }^{5}$. During this period the historiography credited the old and polemical idea of Juan of Torquemada according to which the origin of conciliar thought should be searched in the heretical teaching of William of Ockham and Marsilius of Padua ${ }^{6}$. Thus, the text of the Haec sancta was bluntly brushed aside from the catholic tradition. Even such a perceptive and skilled historian as J. Hefele who had been working on his monumental Conciliengeschicte, fell victim of this intellectual climate and affirmed that the question of the decree should be solved on canonical terms ${ }^{7}$. Nevertheless, in the work of some of the most important scholars of medieval political thought, as for example, O.Gierke, F. Bliemetzrieder, H.-X. Arquillière and W. Ullmann we feel a great unrest about the supposedly heretical origins of conciliar thought. In fact, most of them started to suggest that its real source might be searched in the corpus of canonical texts regulating the life of ecclesiastical corporations during the XII and XIII centuries. However, none of them made a systematical study about this corpus ${ }^{8}$.

4 Although the decree Pastor aeternus approved by the Vatican Council I had created a context particularly opposed to conciliar studies, during this period the specialized historiography started to increase the conciliar collections of sources of J. D. Mansi and H. Van der Hardt. Few years after the Vatican Council I, H. Finke started the publication of the Acta Concilii Constantiensis ${ }^{9}$.

5 Anyway, conciliar thought continued to be considered as something essentially alien to the catholic tradition. F. Oakley has studied how these theological criteria distorted the historical vision of the conciliar tradition since most of the instrumenta, theological Dictionaries and Catholic Encyclopedias tended to create a vacuum memoriae between the Council of Vienne (1311-1312) and the Council of Florence (1439-1445) ${ }^{10}$. In the same sense, the publication of the Codex Iuris Canonicis affirmed without restrictions on its canon 1556 the principle of the Prima Sedes a nemine iudicatur ${ }^{11}$. Even as late as 1947, Angelo Mercati, the Prefect of the Vatican Library published a list of popes in which against all historical criteria the popes of the Pisan line were considered as anti-popes while the Roman ones were considered legitimate ${ }^{12}$.

6 The publication of B. Tierney's Foundations of Conciliar Theory was a serious blow for this hermeneutical paradigm that had been operating since the times of the Vatican Council I. In his study, B. Tierney proved what had been suggested previously: the real source of conciliar thought should be searched inside the catholic tradition. The sources of these ideas were on the one hand, the body of canonical texts interpretating 
the structure of the Universal Church in terms of ecclesiastical corporations and on the other hand, those glosses of the Decretum commenting the case of an heretical pope ${ }^{13}$.

In this context, the call for the Vatican Council II created an institutional frame much more favorable to conciliar studies since now many scholars were deeply interested in recovering the conciliar precedents. Following these tendencies at the beginning of the 60 ' P. De Vooght suggested from an historical point of view the potential contradictions between the Pastor aeternus of the Vatican Council I and the Haec sancta approved by the Council of Constance ${ }^{14}$. Despite P. De Vooght's cautious conclusion, the reaction against his view soon took place under the feather of J. Gill, the Director of the Pontifical Oriental Institute who restated the old polemical arguments which considered the Haec sancta an heretical intent to subvert the Church constitution desired by God ${ }^{15}$. Even if he thought he could justify his position from an historical point of view, once again the theological and canonical criteria conditioned the interpretation. During this early period immediately after the call of the Vatican Concil II, the main topic of the debate was centered on the dogmatic validity of the Haec Sancta. The first catholic scholar to extract the theological conclusions from this decree was the Tübingen professor, H. Küng. Far from claming a radical conciliar supremacy, he proposed a much more active role of the Council, but only in the cases of papal heresy or schism ${ }^{16}$. According to F. Oakley's last book about conciliar thought the debate about the dogmatic validity of the Haec sancta has never been definitely solved neither by theological nor by historical arguments ${ }^{17}$. The Constitutional decree Lumen gentium approved by the Vatican Council II did not pronounce the last word about the issue. Even if this decree recognized the collegial and Episcopal magisterium of the Church, at the same time left the door open for curial centralism ${ }^{18}$.

8 Since the polemics on the dogmatic validity of the Haec sancta had finished in a real culde-sac, at the end of the 60 ' the focus of the debate changed. From this moment onwards the center of the debate has been the legal validity of the decree as a positive constitutional law ${ }^{19}$. Some Church historians as H.Jedin, W. Brandmüller and A. Franzen without refusing the validity of the Haec sancta, have been trying to establish its limits. According to their theory (later called Notstandigtheorie), the decree was only an emergency measure with the scope of solving merely the particular situation caused by the Schism ${ }^{20}$. In fact, a similar interpretation had already been suggested by $\mathrm{J}$. Hollensteiner some years before ${ }^{21}$. However, the first problem of the Notstandigtheorie was the following: if the Haec sancta was only an emergency measure, how would they explain the meaning of the sentence cuiscumque alterius concilii generalis legitime congregati?

9 W. Brandmüller's restricted interpretation affirmed that the council fathers were alluding through these words merely to the possible need of another council to put an end to the schism ${ }^{22}$. Therefore, they had used the term alterius instead of alii. Nevertheless, as it has been suggested by F. Oakley, W. Brandmüller's interpretation tended to reduce the importance of the term cuiscumque ${ }^{23}$.

10 Anyway, we think that the main problem of the Notstandigtheorie is related to the reconstruction of the immediate context in which the decree was approved. In Brandmüller's interpretation the existence of three lines of doubtful claimants to the papal offices created a situation of a de iure quasi-vacancy. Therefore, the popes had been ipso facto (by their own heretical act) deposed without a public process ${ }^{24}$. Following this line of thought, the sentence of the decree affirming etiam si papalis 
existat should be translated in this way: '...selbst wenn ein Ihaber päpslicher Würde existieren sollte.' This fragment would prove that the council fathers did not need to act through a process of deposition against the papal office ${ }^{25}$. Instead they would have followed the canonical opinio properly represented by Hugucio of Pisa's gloss about a pope whose heretical behavior would automatically put him out of his office ${ }^{26}$.

11 However, we believe that the situation that the Council had to face was radically different since the Council had been convoked by John XXIII whom most of the council fathers considered as a legitimate pope. In F. Oakley's view, it is important to point out that he was the only pope called dominus papa in the deposition sentence. If the council fathers had followed the ipso facto theory, at the same time they would have cast doubts on the legitimacy of a Council convoked by an heretical head ${ }^{27}$. Even if we agree with Brandmüller's translation of the etiam si paplis existat, we tend to disagree with his conclusions. Wouldn't be possible to affirm that the council fathers used this sentence etiam si papalis existat to allude to the fact that although the formalities of the process of deposition had started, a sentence had not yet been asserted? We have to remember that the sentence will be read later ( $29^{\text {th }}$ may). This might be the reason why the council fathers decided to include this phrase ${ }^{28}$.

12 At this point we can try to draw some conclusions about the Notstandigtheorie. We think that one of the fundamental premises of this theory relies on the effort to harmonize the canonical principle of Prima Sedes a nemine iudicatur with the historical facts. This effort of course makes their supporters pay an important hermeneutical price since they are forced to adapt historical data to canonical principles.

13 The supporters of the Notstandigtheorie never recognized that next to Hugucio's ipso facto deposition theory, the canonical tradition had developed another line of thought completely different affirming the need of the public process of deposition in the case of an heretical pope. This tradition had its origins in the Summa De Iure Canonico Tractaturus (xII century) ${ }^{29}$ and it had been later developed between others by the canonist Alanus Anglicus (xIII century) whose Apparatus Ius Naturale ${ }^{30}$ became a classical reference about this issue. In opposition to W. Brandmuller's view we feel inclined to think that the council fathers decided to follow this second canonical theory since they needed to demonstrate through a deposition process that John XXIII previously a legitimate pope who had convoked the Council, had became only later an heretic. It should be remembered that during this period J.Gerson had corrected his De auferibilitate papae in which he defended the need of a public process of deposition ${ }^{31}$. One of the most important premises of the Notstanditheorie is to affirm that the need of a deposition trial would imply to accept the fact that the council fathers would have followed a 'radical' conciliarism. In fact, the council fathers were far from affirming a 'radical' conciliariar superiority as later expressed by de Basel Council. However, we think that the fact of affirming the need of deposition process should be understood as a conservative strategy whose aim was to emphasize and strengthen the position of the Council as the most important hierarchical instance in charge of setting the limits of orthodoxy in a context of extreme institutional weakness.

14 At the same time, we think that the need of a process of deposition in the case of and heretical pope should be understood in relation to the rest of the causae fidei, mainly the inquisitorial processes against J. Wyclif and J. Hus and the condemnation of the thesis of J. Petit. The council fathers were aware of the potential risks that would follow, if the theory of the ipso facto deposition was projected to the rest of the 
ecclesiastical hierarchy and to the secular politeia. In their view this risk appeared with certain evidence in the teaching of J. Wyclif and J. Hus who with differences between them affirmed that a priest in mortal sin ipso facto would have lost his authority to administrate valid sacraments ${ }^{32}$. At this point it is important to remember that between the end of the xivth century and the beginning of the xvth century there had been a revival of some 'neodonatist' thesis affirming that the sinful state of a priest in possession of an ecclesiastical office affected the validity of his acts. On the one hand, these ideas weakened the entire hierarchical and sacramental structure of the Church while on the other hand, they left the door open for secular intervention of the princes when the priests did not fulfill their evangelical duties. The ipso facto deposition theory implied the recovery of another canonical principle affirming that the Pope could be deposed without a process because his own heretical act had turned him minor quolibet catholico. This principle which had been of great importance for William of Ockham in his fight against the papacy in the xivth century, became during the Council of Constance a principle that due to its anarchical implications, should be expressly rejected and avoided ${ }^{33}$. In a similar fashion, the teaching of J. Petit about tyrannicide stating that a tyrannical prince could be deposed or killed without a due public process was a potential risk that would follow from the ipso facto theory. To counteract this risk once again J. Gerson in his De auferibilitate Papae felt compelled to state clearly that it was not possible for a subject to act against his ruler without a proper declaratione iudiciaria ${ }^{34}$. The council fathers in Constance had to face the difficult situation of deposing an heretical pope and at the same time reconstructing the bonds of obedience from below. Therefore, the inquisitorial processes appeared as well fitted instance to do this.

Concluding this presentation, we can suggest from a methodological point of view that the synodial practices (symbolical, liturgical and also judicial) carried with them the traces of the intense ecclesiological debates that had taken place within the Council of Constance. If the study of the symbolical and liturgical practices has shed great results, the study of the judicial practices has not yet fully exploited all its potentialities since the inquisitorial processes have been studied exclusively from a theological point of view ${ }^{35}$. If we study the judicial practices with one eye on the ecclesiological debates, this would give us a twofold advantage. On one side, we could understand better the harsh and violent response of the Constance in the causae fidei, while on the other side we could trace some indices that would allow us to discover how did the council fathers understand the conciliar authority they had affirmed in the text of the Haec sancta. Sometimes it is in the field of the practice that the actors reveal some essential trends.

\section{Appendix}

Et primo (declarat), quod ipsa in spiritu sancto legitime congregata concilium generale faciens, et ecclesiam catholicam repraesentans, potestatem a Christo immediate habet, cui quilibet cuiuscumque status vel dignitatis, etiam si papalis existat, obedire tenetur in his quae pertinent ad fidem et extirpationem dicti schismatis, ac reformationem dictae ecclesiae in capite et in membris.

Item, declarat, quod quicumque cuiuscumque conditionis, status, dignitatis, etiam si papalis (fuerit), qui mandatis, statutis seu ordinationibus, aut praeceptis huius sacrae synodi et cuiuscumque alterius concilii generalis legitime congregati, super praemissis, seu ad ea pertinentibus, factis, vel faciendis, obedire contumaciter contempserit, nisi 
resipuerit, condignae poenitentiae subiiciatur, et debite puniatur, etiam ad alia iuris subsidia, si opus fuerit, recurrendo.

\section{NOTES}

1. G. ALBERIGO, et alli (éds.), Conciliorum Oecumenicorum Decreta (COD), Bâle, 1962, p. 383 : «Item quod istud sacrum concilium non debet, disolví, nec dissolvatur usque ad perfectam extirpationem praesentis schimatis, et quousque ecclesia sit reformata in fide et in moribus, in capite et in membris. »

2. COD, p. 383 : «Et primo declarat, quod ipsa in Spiritu sancto legitime congregata, generale concilium faciens, et ecclesiam catholicam militantem repraesentans, potestatem a Christo immediate habeat, cui quilibet cuiuscumque status vel dignitatis, etiamsi si papalis existat, obedire tenetur in his quae pertinent ad fidem et extirpationem dicti schismatis." Some sectors inside the College of Cardinals whose more important representative was F. Zabarella did not want to accept the fact that the Council possessed legitimate authority to enact reform without the papal head. On the role played by cardinal F. Zabarella, cf. Th. MORRISEY, « The Decree 'Haec Sancta' and Cardinal Zabarella. His Role in its Formulation and Interpretation " in Annuarium Historiae Conciliorum, 10, 1 (1978), p. 145-176 ; Th. MORRISEY, « Cardinal Zabarella and Nicholas of Cusa. From Community Authority to Consent of the Community» in Mitteilungen und Forschungsbeiträge der Cusanus-Gesellschaft, 17 (1986); Th. MORRISEY, «Ein Unruhiges Leben. Franciscus Zabarella an der Universität von Padua (1390-1410)», in Mitteilungen und Forschungsbeiträge der Cusanus-Gesellschaft, 24 (1998); Th. MORRISEY, "The Call for Unity at the Council of Constance: Sermons and Adresses of Cardinal Zabarella, 1415-1417 ", in Church History, vol. 53, n 3, 1984, p. 307-318; M. DECALUWE, «Three Ways to Read the Decree Haec Sancta (1415). The Conciliar Theories of Franciscus Zabarella and of Jean Gerson and the Traditional Papal View on General Councils » in G. CHRISTIANSON, Th. IZBICKI y Ch. BELLITO (dir.), The Church, the Councils and Reform: The Lessons of the Fifteenth Century, Catholic University of America Press (in press). I would like to thank the author for having granted me the possibility of acceding to his text before its publication.

3. COD, p. 385 : «Et primo declarat, quod ipsa in Spiritu sancto legitime congregata, generale concilium faciens, et ecclesiam catholicam militantem repraesentnas, potestatem a Christo immediate habet, cui quilibet cuiuscumque status vel dignitatis, etiamsi si papalis existat, obedire tenetur in his quae pertinent ad fidem et extirpationem dicti schismatis ac generalem reformationem dictae ecclesiae Dei in capite et in membris. " The absence of F. Zabarella and other cardinals in this session is significant. Nevertheless, evidences do not exist to question the ecumenical character of the session. Cf. about this matter G. ALBERIGO, Chiesa concilare: Identità $e$ significato del conciliarismo, Brescia, 1981, p.150-165 ; MORRISEY, "The Decree 'Haec Sancta'...", op.cit.; M. DECALUWE, "Three Ways to Read the Decree...", op.cit.; B. TIERNEY, Foundations of Conciliar Theory. The Contribution of the Medieval Canonists from Gratian to the Great Schism [enlarged new edition], Leiden, 1998, p. 199-214 et W. ULLMANN, The Origins of the Great Schism, Connecticut, 1972, p. 191-231.

4. For the text of the Haec Sancta we will use the version proposed by M. Decaluwe, «A new and disputable text-edition of the decree Haec Sancta of the Council of Constance (1415)», in Cristianísimo nella storia, 32, 2 (2006), p. 417-445. The author indicates that although the edition of 
the COD is in general reliable, from a philological point of view, however it does not offer the best version of the decree since it is based exclusively on the edition of the text of Van der Hardt who used slightly reliable manuscripts (from the German libraries of Wolfenbüttel's cities, Vienna, Leipzig, Gotha, Erfurt and Berlin). The author also mentions that the Council of Basel (1431-1449) created a commission to re-edit the Acts of the Council of Constance. This commission used as source the text Liber of Brogny's Cardinal (Bronchiaco) handed to the Council in 1442. When the cardinal died in 1426 the text finished in the hands of the Genevan Francisco de Meez who authorized the commission to used it. The proposal of the editor is to use as a base text the one published by P. CRABBE, Concliorum Omnium tam Generalium quam Particularium, I-III, Coloniae Agrippinae, 1551, t. II, p. 1080 y 1020. This text reproduces Hieronymus of Croaria's manuscript Acta situ dignísima doteque concinnata Constanciensis concilii celebratissime (1490) on which Johannes Rynmann based in 1500 his first printed edition of the Acts. Most of the later editions will use as base this text. The author confronts its with an important quantity of manuscripts of the xvth century from the Vatican Library (Pal. Lat. 595, Reg. Lat. 981, Reg. Lat. 1031, Rossianus 1064, Vat. Lat. 1335 (1423), Vat. Lat. 4173, Vat. Lat. 4174, Vat. Lat. 4175, Vat. Lat. 4176, Vat. Lat. 4178, Vat. Lat. 4179, Vat. Lat. 4942 (1438), Vat. Lat. 4943 (after the Council of Basel), Vat. Lat. 4984 (from the end of the xvth century), Vat. Lat. 5597, Vat. Lat. 5598 (1421), Vat. Lat. 7297. About the ambiguity in the wording of the decree Cf. B. TIERNEY, « Hermeneutics and History. The Problem of the Haec sancta " in T. A. SANDQUIST, M. R. POWICKE (éds.), Essays in Medieval History presented to Bertie Willkinson, Toronto, 1969, p. 354-370. According to his view the text would have been deliberately ambiguous about the meaning of the word concilium. While on the first part of the Haec Sancta should be interpreted as a council acting without the Pope, in the second part the text would refer to the council acting together with the Pope. In any case B. Tierney emphasizes the ambiguity of the important term concilium. Th. MORRISEY, "The Decree 'Haec Sancta'... » op. cit., p. 159. Th. Morrisey affirms that the council had never solved what would happend in the case of disputes between the authority of a legitimate council and a legitimate pope; M. DECALUWE, "Three Ways to Read the Decree... », op. cit. More than its ambiguity, M. Decaluwe emphasizes the importance of the text wording as an instrument to generate consensus between the different positions about the authority of the council in absence of the Pope.

5. On papal infallibility and its historical origins Cf. B. TIERNEY, The Origins of Papal Infallibility 1150-1350, Leiden, 1988 and B. TIERNEY, Rights, Law and Infallibility in Medieval Thought, Variorum, Norfolk, 1997. Cf. the text of the decree Pastor aeternus COD (812) : «Docemus itaque declaramus, iuxta evangelii testimonia primatum iurisdictionis in universalem Dei ecclesiam immediate et directe beato Petro apostolo promissum atque collatum a Christo domino fuisse [...] Atque uni Simoni Petro contulit Iesus post suam resurrectionem summi pastoris et rectoris iurisdictionem in totum suum ovile, dicens: Pasce agnos meos: pasce oves meas. » COD (813) : « Quapropter apertis innixi sacrarum litterarum testimoniis, et inhaerentes tum praecessorum nostrum Romanorum pontificum, tum conciliorum generalium disertis, perspicuisque decretis, innovamos oecumenici Florentini definitionem, qua credendum ab omnibus Christi fidelibus est, sanctam apostolicam sedem et Romanum ponfificem in universum orbem tenere primatum, et ipsum pontificem Romanunm successorem esse beati Petri principis apostolroum, et verum Christi vicarium totiusque ecclesiae caput, et omnium christianorum patrem ac doctorem existere; et ipsi in beato Petro pascendi, regendi ac gubernandi universalem ecclesiam a domino nostro Iesu Christo plenam potestatem tradita esse; quemadmodum etiam in gestis oecomenicorum conciliorum et in sacris canonibus continetur. Docemus proinde et declaramus ecclesiam Romanam, disponere Domino, super omnes alias ordinariae potestatis obtinere principatum, et hanc Romani pontificis iurisdictionis potestatem, quae vere episcopalis est, immediatam esse: erga quam ciuscumque ritus et dignitatis pastores atque fideles, tam seorsum singuli quam simul omnes, officio hierarchiae subordinationis, veraeque obedientiae obstringuntur, non solum in rebus, quae ad 
fidem et mores, sed etiam in iis, quae ad disciplinam et regimen ecclesiae per totum orbem diffusae pertinent; ita ut custodita cum Romano pontifice tam communionis, quam eiusdem fidei professionis úntate, ecclesia Christi sit unus grex sub uno summo pastore.»

6. Cf. the papal bull of Eugenius IV of April 20, 1441 affirms: «Fuerunt impietatis alii dyabolici fundadores: Marsilius de Padua, Johannes de Ganduno, Guillermus Ocham aliique nonnulli, qui non tantum sui temporis, sed eciam futuri seculi homines venerarunt (Concilium Florentinum Ep. Pont. I n. 248 28, p. 7-9) and the text of Juan de Torquemada's Summa cap. C, II, Venetiis 1561 : «Ubi non parum admirandum adversarios basilenses tanta caligine mentis involutos et excecatos malitia, ut in materias fidei diffiniendis et declarandis maluerunt sequi homines ab ecclesia Dei in doctrina sua damnatos: sicut fuit Marsilius de Padua, Ockham, cum complicibus suis, ex quorum doctrina extracta sunt pro magna parte decreta illa praefata Basilensia et quosdam alios novellos doctorellos praefati Ockham et aliquorum fraticellorum opiniones erroneas renovantes... » Both texts are quoted by G. ALBERIGO, Chiesa concilare, op. cit., p. 18 n. 16. It is very usefull about this topic the text of Th. IZBICKI, « Paplist Reaction to the Council of Constance: Juan de Torquemada to the Present», Church History, 55, 1 (1986), p. 7-20. About the bull Cf. R. BÄUMER, "Die Stellungnahme Eugens IV. zum Konstanzer Superioritätsdekret in der Bulle 'Etsi non dubitemus' » in A. FRANZEN, W. MÜLLER (éds.), Das Konzil von Konstanz. Beiträge zu seiner Geschichte und Theologie, Fribourg, 1964, p. 337-354.

7. Cf. the words of J. Hefele quoted by H. SCHNEIDER, Der Konziliarismus als Problem der neueren katolischen Theologie, Berlin/New York, 1976, p. 265 : «Hiernach und nach dem heutigen Recht, welches die päpstliche Approbation der allgemeinen Concilien, um sie zu solchen zu machen, für nöthig erklärt, kann es wohl keinem Zweifel unterliegen, daß a. alle Beschlüsse von Konstanz, welche für das Papstthum keine Präjudiz tilden, für ökumenisch zu erachten, dagegen $b$. alle, welche gegen das ius, die dignitas und praeminentia des apostolischen Stuhls verstoßen für reprobirt zu halten sind. »

8. About this cf. F. OAKLEY, «Verius est licet difficilius. Tierney's Foundations of Conciliar Theory after forty years» in F. OAKLEY, Politics and Eternity. Studies in the History of Medieval and EarlyModern Political Thought, Leiden, 1999, p. 75.

9. J. D. MANSI, Sacrorum conciliorum nova et amplissima collectio, vol. XXVII/XXVIII, Florentiae, Venetiis, Paris, Lipsiae, 1759 [Reproductio typographica 1966]; H. VAN DER HARDT, Magnum oecumenicum Constantiense concilium, 6 vol., Fracofurti-Lipsiae, 1696-1700 (Indices 1742); About the work of H. FINKE (ed.), Acta Concilii Constanciensis, Münster, 1896-1928. K. A. FINK, « Zu den Quellen für die Geschichte des Konstanzer Konzils» in A. FRANZEN, W. MÜLLER, (éds.), Das Konzil von Konstanz..., op. cit., p. 471-476 and A. FRENKEN, «Die Erforschung des Konstanzer Konzils (1414-1418) in den letzten 100 Jahre ", Annuarium historiae conciliorum, 25 (1993), p. 30-89.

10. F. OAKLEY, Council Over Pope? Towards a Provisional Ecclesiology, New York, 1969, p. 122-124. The study of the author includes even other instrumenta with similar visions.

11. Codex Iuris Canonici, Pii X Pontificis maximi iussu digestus Benedicto Papae XV auctoritate promulgatus, Card. Gasparri (ed.), Roma, 1918, Sectio I, Titulus I, De foro competenti, Can. 1556. "Prima Sedes a nemine iudicatur. » The nisi a fide devius conditional clause is excluded. Usually it was quoted accompanying this text in the canonical tradition. On this phrase and its origins cf. J. M. MOYNIHAN, Papal Immunity and Liability in the Writings of the Medieval Canonists, Roma, 1961, p. 25-42.

12. F. OAKLeY, Council over Pope ?..., op. cit., p. 125. Cf. also Annuario Pontificio (Città del Vaticano, 1947) and the text quoted by the author A. MERCATI, "The new List of Popes ", Mediaeval Studies, 9 (1947), p. 71-80. F. Oakley explains that A. Mercati never used historical criteria to affirm that during the Schism the only legitimate line of popes was the Roman one. His option for this line was based on the theological criteria prevailing since the time of the Council Vatican I. He also mentions a curious event about the decision taken by the Pope in 1958 of assuming the name of 
John XXIII. When the Pope announced that he would adopt this name, he mentioned the fact that there had been already 22 pontiffs with this name extra legitimitatis discussiones. Thus, the Pope omitted with caution to give his opinion about the legitimacy of the Pisan line (we have to remember that John XXIII had been deposed by the Council of Constance). Nevertheless, in the official reissue of the speech of the Pope in the Acta Apostolicae Sedis the words legitimitatis discussiones were omitted since they were not compatible with the position adopted in the Annuario Pontificio.

13. B. TIERNEY, Foundations of Conciliar Theory, op. cit., p. $240:$ « But side by side with this [familiar doctrine of papal sovereignty] there existed another theory, applied at first to single churches and then at the beginning of the fourteenth century, in a fragmentary fashion, to the Roman Church and the Church as a whole, a theory which stressed the corporate association of the members of the church as the true principle of ecclesiastical unity and which envisaged the exercise of corporate authority by the members of a Church even in the absence of a collective head. »

On the work of B. Tierney, cf. F. OAKLEY, Council over Pope ?..., op. cit., p. 80 and especially about the relevance B. Tierney's thesis cf. F. OAKLEY, « Verius est licet difficilius... », op. cit., p. 76-77. By no means B. Tierney tried in his study to write a complete history of conciliar thought. As he explicitly declared it, he was only emphasizing the contributions of canonical thought. The moderate proposal of B. Tierney has not been recognized specially by R. BÄUMER, «Die Erforschung des Konziliarismus» in R. BÄUMER, Die Entwicklung des Konziliarismus: Werden und Nachwirken der conciliaren Idee, Darmstadt, 1976, ps. 29-34. This was emphasized specially in a book review written by M. SEIDMAYER, in Zeitschrift der Savigny-Stifung für Rechtgeschichte. Kan. Abt. 74, 1957, p. 374-387.The most important critic of B. Tierney's thesis can be found in C. FASOLT, Council and Hierarchy. The Political Thought of William Durant the Younger, Cambridge, 1991, p. 19.

From the quotation of certain texts proposed by H.J. SIEBEN, Die Konzilsidee des lateinischen Mittelalters (847-1375), Padeborn, 1984, p. 255 affirming that the Council depended on the papal summons, C. Fasolt saw a real assault to the thesis of B. Tierney. Nevertheless, these affirmations by no means made collapse his thesis, since at the same time these texts were affirming that in certain questions related to faith and to the state of the Church, the Pope had to accept the conciliar authority. About this polemic cf. B. TIERNEY, "Introduction" of the last reissue of Foundations of Conciliar Theory (1998), op. cit., p. 13 and F. OAKLEY, « Verius est licet difficilius... » op. cit., p. 75.

14. The first conclusions appeared in P. DE VOOGHT, «Le Conciliarisme aux conciles de Constance et Bâle », B. воттE (éd.), Le Concile et les Conciles: Contribution à l'histoire de la vie conciliaire de l'église, Chevetogne-Paris, 1960, ps. 143-181 ; P. DE VOoGHT, « Le conciliarisme aux conciles de Constance et Bâle: compléments et précisions ", Irénikon, v. 36, n 1 (1963), p.61-75 and P. DE VooHT, «Le Cardinal Cesarini et le Concile de Constance » in A. FRANZEN, W. MÜLlER, (eds.), Das Konzil von Konstanz..., op. cit., 1964, p. 357-381. About the changes in his opinion cf. P. DE VOOHT, Les pouvoirs du Concile et l'Autorité du pape au Concile de Constance, Paris, 1965 (Unam Sanctam) and P. DE VOOHT, «Resultados recientes de la investigación histórica sobre el conciliarismo », Concilium, 64 (1971), p. $125-131$.

15. J. GILL, The Council of Florence, Cambridge, 1959 ; J. GILL, Eugenius IV, Londres, 1961 ; J. GILL, « The fifth Session of the Council of Constance ", Heythrop Journal, V, 1964, p. 131-147 ; J. GILL, Constance et Bâle-Florence, Paris, 1965 and J. GILL, «Il decreto Haec sancta synodus del concilio di Constanza », Revista di storia della Chiesa in Italia, XII (1967), p. 123-130 y J. GILL, «Die funfte Sitzung des Konzil von Konstanz » en R. BÄUMER, Das Konstanzer Konzil, Darmstadt, 1977, p. 229-247. His argument consisted in affirming that the Council of Constance was not legitimate since its authority depended on the previous Council of Pisa. Against strong historical evidence, J. Gill thought that this last council had not been ecumenical. According to this author the Council of Constance only 
became a legitimate assembly when Gregory XII, the Pope of the roman obedience, was allowed to convoke it on the $4^{\text {th }}$ July 1415 . In addition, according to J. Gill, the Haec Sancta had never received papal approval since it had not been named explicitly in a bull. In order to put in doubt the validity of the decree, the author denied the ecumenical character of the $5^{\text {th }}$ session. From the absence of certain cardinals (especially of Zabarella) he arrived to this conclusion. Although the author thought he was debating strictly on historical terms, canonical and theological criteria permanently distorted and forced his interpretation.

16. Cf. H. KÜNG, Strukturen der Kirche, Freiburg, 1962, p. 259 : «Was wurde also, wenn wir das Ergebnis des Konzils für unieren Problemkreis zusammenfassen wollten, in Konstanz definiert? Nicht definiert wurde der konziliare Parlamentarismus (im Sinne des radikalen Konziliarismus): nach disem wäre die gewöhnliche ordentliche Leitung der Kirche vom Papst auf das Konzil übertragen worden und der Papst zu einem untergeordneten Executivorgan des konziliaren Parlaments degradiert [...] Definiert wurde aber jedenfalls eine bestimmte Art von Superiorität des Konzils (im Sinne eirner, wenigstens gemäßigten, « konziliaren Theorie ») : darnach hat das ökumenische Konzil nicht nur für den damaligen Notfall, sondern auch in Zukunft die Funktion einer Art von «Kontrollinstanz» ubre den Papst, dessen Versagen in Häresie, Schisma usw. Grundsätzlich ja auch in Zukunft möglich war. »

17. Cf. F. OAKLEY, The Conciliarist Tradition. Constitutionalism in the Catholic Church 1300-1870, Oxford, 2003, p. 90.

18. About the decree Lumen gentium Cf. COD (863) : « Haec sacrosanta synodus, concilii Vaticani primi vestigia premens, cum eo docet et declarat Iesum Christum pastorem aeternum sanctam aedificasse ecclesiam, missis apostolis sicut ipse mussus erat a Patre (cf. Io 20, 21) quorum successores, videlicet episcopos, in ecclesia sua- usque ad consummaitonem saeculi pastores esse voluit. Ut vero episcopatus ipse unus et indivisus esset, beatum Petrum ceteris apostolis praeposuit in ipsosque instituit perpetuum ac visibile unitatis fidei et cummunionis principium et fundamentum. Quam doctrinam de institutione, perpetuitate, vi ac ratione sacri primates Romani pontificis deque eius infallibili magisterio, sacra synodus cunctis fidelibus firmiter credendam rursus proponit, et in eodem incepto pergens, doctrinam de episcopis, successoribus apostolorum, qui cum successores Petri, Christi vicario ac totius ecclesiae visibili capite, domum Dei viventis regunt, coram omnibus profiteri et declarare constituit. " About the overlapping of the constitucional principle of the roman primacy and episcopal collegiality cf. B. TIERNEY, "Introduction », Foundations of Conciliar Theory, op. cit., p. 27-29 y H. RIEDLINGER, « Hermeneutische Überlegungen zu den Konstanzer Dekreten» in A. FRANZEN, W. MÜLLER (eds.), Das Konzil von Konstanz..., op. cit., p. 214-238.

19. About the validity of the decree as a constitutional positive law Cf. B. TIERNEY, « Hermeneutics and History. The Problem of the Haec santa ", op. cit., p. 363.

20. H. JEDIN, Bischofliches Konzil oder Kirchenparlament? Ein Beitrag zur Ecklesiologie des Konzilen von Konstanz und Basel, Bâle/Stuttgart, 1965 ; A. FRANZEN, « El Concilio de Constanza: problemas, tareas y estado actual de la investigación sobre el Concilio », Concilium, 7 (1965) p. 31-77. This article summarizes the position of the author about this matter. Cf. also the articles : A. FRANZEN, «Zum Vorgeschicthe des Konstanzer Konzil vom Ausbruch des Schismas bis zum Pisanum»; "Das Konzil der Einheit: Einigung bumühungen und Konziliaren Gedanken auf dem Konstanzer Konzil. Die Dekrete 'Haec sancta' und 'Frequens'» en A. FRANZEN, W. Müller (eds.) Das Konzil von Konstanz..., op. cit, p. 3-35 and p. 69-112; W. BRANDMÜLLER, «Besitzt das Konstanzer Dekret 'Haec sancta' dogmatische Verbindlichkeit?», Annuarium Historiae Conciliorum, 1 (1969), p. 96-113; more recently W. BRANDMÜLLER, Das Konzil von Konstanz (1414-1418), Paderborn, 1991, p. 237-259. About the Notstandigetheorie Cf. H. SCHNEIDER, Der Konziliarismus als Problem der neueren katolischen Theologie, op. cit., p. 226-234. 
21. J. HOLLNSTEINER, "Das Konstanzer Konzil in der Geschichte der christlichen Kirche» in Mitteilungen des österreichen Instituts für Geschichtsforschung, 11, (1929), p. 395-420.

22. W. BRANDMÜLLER, Das Konzil von Konstanz, op. cit., p. 256 : «Wenn dem nun hinzugefurt wird ... et cuiscumque alterius concili i... dann geht es auch dabei um das Ziel von Einheit und Reform. Deshalb kann es nicht angehen, wie üblich zu übersetzen: ... und eines jeden anderen Konzils... Es muß viel mehr übersetzt werden: und jedes weiteren Konzils, das bei einem eventuellen Scheitern dieses Konstanzer Konzils notwendig werden könnte. »

23. F. OAKLEY, The Conciliarist Tradition. Constitutionalism in the Catholic Church 1300-1870, op. cit., p. 92-93.

24. W. BRANDMÜlleR, Das Konzil von Konstanz, op. cit., p. 247: "Soll nun der Versuch einer den Ertrag der bisherigen Diskussion würdigenden Interpretation dieses bedeutenden Textes unternommen werden, so ist zunächst eine Voraussetzung von Gewicht: Kaum einer der einigermaßen informierten Konzilsteilnehmer konnte darüber im unklaren sein, daß keiner der drei konkurrienden 'Päpste' unbezweifelt und unbezweifelbar legitimer Papst war. Deshalb bestand de iure Sedisvakanz. » About the process of deposition cf. W. BRANDMÜLLER, Das Konzil von Konstanz, op. cit., p. 299 : «Dies aber auch aus einem noch viel gewichtigeren Gund: Johann XIII. war keinesfalls zweifelsfrei legitimer Inhaber der Cathedra Petri gewesen. Die öffentliche Meinung auf dem Konzil war sich dessen sicher. Johann XXIII hatte in seiner Obedienz de facto als Papst fungiert, de iure jedoch kaum. Wovon konnte er dann abgesetzt, wessen konnte er dann priviert warden? Der faktischen Verfügung über die im Bereich seiner Obedienz gelegenen bona temporalia der Kirche, insbesondere ubre den Kirchenstaat. Nicht jedoch des obersten Hirtenämtes der Kirche! Damit ist auch die Frage beantwortet, ob denn das Konzil von Konstanz gegen den Grundsatz prima sedes a nemine iudicatur gehandelt habe. Es is zu Konstanz kein wirklicher, legitimer Papst, wirklich abgesetzt worden. "

25. W. BRANDMÜlLER, Das Konzil von Konstanz, op. cit., p. 255 note 64 : «Daß dieser landläufig mißverstanden wird, zeigen die Übersetzungen desselben, denen man begegnen kann. Th. MORRISEY übersetz etwa so: everyone of whatever status or dignity is bound to obey it..., even if it be the papal dignity. Ganz ähnlich G. ALBERIGO : ... chiunque, di qualunque condizione e dignità, compresa quella papale. Diese Übersetzungen, vor allem die letztere, sind eindeutig falsch. Sie geben das etiam si ... existat nicht nur ungenau, sondern gar nicht wieder. Dieses aber müßte übersetzt werden: selbst wenn ein Inhaber päpstlicher Würde existieren sollte." For the text of the translation cf. Th. MORRISEY, «The Decree 'Haec Sancta' and Cardinal Zabarella... », op. cit., p. 154 y COD 409.

26. One of the most important glosses on this issue was that of Hugucio of Pisa. It was one of the first serious attempts to discuss the problem of an heretical pope. He might be deposed because his behaviour would harm the whole Church : « ... si papa esset hereticus non sibi soli noceret sed toti mundo, praesertim quia simplices et idiote facile sequerentur illam heresim cum crederent non esse heresim. » The reasoning is clear; if the Pope was heretical, the simple fideles would tend to follow his position without knowing the heresy manifested and this would be particularly harmful to the whole Church. Hitherto Hugucio's gloss seemed to follow the text of the Decretum. Nevertheless, the innovation of Hugucio's text consisted in incorporating a series of crimes beyond heresy which were particularly harmful to the Church since they were committed by the Pope. These were crimes that due to their public and manifest character would damage the statum ecclesiae. Hugucio asked himself rhetorically : «Ecce, publice furatur, publice fornicatur, publice comittit simoniam, publice habet concubinam, publice eam cognoscit in ecclesia iuxta vel super altare, admonitus non vult cessare, nunquid non accusabitur... nunquid non condempnabitur, nunquid sic scandalizare ecclesiam non est quasi heresim committere? Preterea contumacia est crimen ydolatrie et quasi heresis ut di. Lxxxi si quis presbyteri, unde et contumax dicitur infidelis ut di. Xxxviii nullus." These crimes scandalizing the Church were practically assimilated to heresy. If the Pope incurred in these public crimes, could be deposed 
having been called previously to modify his conduct. The text of Hugucio's gloss has been quoted by B. TIERNEY, Foundations of Conciliar Theory, p. 228-229. Anyhow Hugucio's gloss also introduced important restrictions since the Pope could only be accused of an already existing heresy and besides this should be affirmed publicly by the Pope. About Hugucio gloss cf. also J. M. MOYNIHAN, Papal Immunity and Liability in the Writings of the Medieval Canonists, p. 75-84. Johannes Teutonicus' Glossa Ordinaria stated: «Dist. 79 c.8. Contra fas... Sed quis erit iudex de hoc, an electio sit contra fas? Non ipsi Cardinales, quia si sic, essent iudices in proprio facto nam nullus superior potest inveniri ut extra de elect. licet. In fi. (c.6). Dic istud c.locum habere quando neuter est ellectus a duabus partibus. Vel dic, quod concilium convocabitur.» Text extracted from the appendix cf. B. TIERNEY, Foundations of Conciliar Theory, p. 230.

27. This is a key premise in our argumentation. Nevertheless, it is necessary to emphasize that this fact has not been noted by most of the scholars. Recently only F. OAKLEY, The Conciliarist Tradition. Constitutionalism in the Catholic Church 1300-1870, op. cit., p. 86 has emphasized the importance of this fact: "There is little or nothing, however, to suggest that the fathers assembled at Constance were themselves disposed to think in such a way. When they proceeded to depose John XXIII they did it so not as a doubtful claimant to the papacy but as pope who had been brought to judgement and found guilty of criminal and incorrigible behaviour." The sententia of deposition of Juan XXIII refers to him as dominum papam. COD, p. 393 : « [Sacrosancta generalis Constnatiensis synodus]... per hanc sententiam definitivam, quam profert in scriptis, pronunciat, decernit et declarat, recessum per praefatum dominum Ioannem papam XXIII ab hac civitate Constantiensi...». On the other hand, although the Council accepted Gregorio's XII convocation as a requirement of his abdication, he was not mentioned as pope. COD, p. 397 : «Sacrosanta generalis synodus Constantiensis, in Spiritu sancto legitime congregate, universalem ecclesiam catholicam repraesentas, cesionem, renuntiationem pro parte illius domini, qui in sua oboedientia dicebatur Gregorius XII... » Finally, the sentence of deposition against Benedicto XXIII also omitted to call him pope. COD, p. 413 : «Quanto magis pereat illius, qui omnes hominess et ecclesiam universalem persecutus est et turbavit, Petri Luna, Benedicti XXII a nonnullis nuncupati, memoria ? ». F. Oakley's position is opposed to W. BRANDMÜLLER's, Das Konzil von Konstanz, op. cit., p. 299 : «Das mindert nicht das Gewicht der Tatsache, daß das Konzil mit seiner Sentenz den Anspruch, dies tun zu können, erhoben hat und realisieren wollte. Indes konnten auch jene, die die konziliaristische Auffassung nicht teilten, der Sentenz zustimmen, da sie sich ja nicht gegen einen legitimen Papst richtete. »

28. About the importance of the procedural formalities cf. Th. MORRISEY, « 'More Easily and More Securely' Legal Procedure and Due Process at the Council of Constance » in J. R. SWEENEY, and S. CHodorow, Popes, Teachers, and Canon Law in the Middle Ages, New York, 1989, p. 234-250. According to the author the Council of Constance always proved to be extremely cautious about them. The article also mentions that the council fathers tried to leave the doors open for a possible collaboration with John XXIII right up to the last moment. The process of negotiation between the Council and John XXIII after his flight has been studied by W. BRANDMÜLLER, Das Konzil von Konstanz, op. cit., p. 279-310. It is important to point out that the deposition sentence will be pronounced only when all the formal requirements of the process were fulfilled. The phrase etiam if papalis existat might be alluding to the fact that since the process had not finished, it $\mathrm{w}$ as not possible to affirm categorically the absence of the Pope. About the second part of the text of the Haec sancta it is interesting the textual variable of « fuerat » introduced by M. Decaluwe. This variable would attenuate the semantic content that $\mathrm{W}$. Brandmüller attributes to the verb « existat» of the first part.

29. Summa De Iure Canonico Tractaturus, Laon, MS. 371 bis. fol. 93 vb, s.v. nisi d(e) p)rehendatur a fide a nemine: « hec negatio notat difficultatem non impossibilitatem quia super alio potest licet difficile quie non nisi notorium fuerit ar. di. xvii concilia (D.XVII, c. 6). ibi de huius modi plenius. 
Set non (num ?) super nova heresi petest accusari. R. sic ut supra dictum est. Set videtur non posse quare (quia?) quamdiu nova est sententia pape super articulo fidei, ei stabitu scilicet quousque fuerit indicio (MS=iudco) U (= universalis ?) concilii approbata. Set tunc non erit nova quid ergo. R. potest dici nova que olim fuit reprobata vel dampnabitur (MS= dampnatibiz), supra qua potest accusari sicut super olim dampnata et hoc postquam super utrumque commonitur (commonitus ?) desistere noluit ut xxiii. Q. iii (sic!) dicit (C. XXIV, q. 3, c.29).» J. M. MOYNIHAN, Papal Immunity and Liability in the Writings of the Medieval Canonists, p. 70-73.

30. AlanUS ANGlicus, Appartus Ius Naturale, Paris, Bib. Mazarine, ms 1318, fol. (this one is longer version of the text, the shorter one is BnF ms 3909) Long Version fol. $15 \mathrm{rb}$ : «Ar. quod in questione fidei maior sinodus quam papa, ar. d. Xv. Sicut (D. XV, c. 2), et d. xvi sancta (D. XVI, c.8), quod firmiter est tenendum, Unde accidit ex tali causa quod sinodus potest ipsum iudicare et dampnare. Unde accidit quod incidit in excomunicationem latam super heresi in sinodo ut hic, quod non accideret si papa in hoc casu maior esset sinodo vel ipsius predicessor alius sine concilio vel collegio cardinalium aliquam heresim dampnasset nec ipsum nec ipsius successorem in dampnatione incidere putarem, licet eumdem errorem foveret, sicut nec hodie papa verberans clericum incideret in canonum » Ibid., C. IX, q. 3, c. 17, fol. 180vb-181ra : « Set queritur cum ipse concilio vel cardinalibus questionem fidei ventilat et contigit papam aliam habere sententiam, aliam cardinales, cuius sententia prevalebit? R. concilii vel cardinalium si omnes in concilium opiniones concordent. Immo etiam si maior pars set si cum papa tanta pars concordaverit quanta est que consensit, pape adhereo, et haec in questione fidei tantum. In aliis autem controversiis iudicabilibus pape sententiam omnium aliorum sententiis prefero. » Ibid., "Set videtur contra xxiii. q. ii sane prefetur (C. XXIV, q. 2, c. 6). ubi dioscorus papa romanus excommunicatus est licet in fide non peccasset. Set iste (?) non fuit papa istius rome set constantinopolis que nova roma appellatur. Item signatur contra xxi. q. ii non licet (C.XII, q. 2, c. 43) ubi papa successoribus videtur legem imponere, et etiam si contra fecerint, excommunicare. Set non es tita, quoniam quod ibi dicitur ad subditos tantum refertur. Est ergo verum quod de sola heresi inuitus potest papa iudicari ut hic dicitur. Set hoc ideo in hoc crimine quia circa ea quae ad fidem pertinent minor est collegio cardinalium vel concilio generali episcoporum. De crimine hereseos tamen si resipiscere voluerit non dampnabitur inuitus ut d. xxi. nunc autem (D. XXI, c. 7). Alii autem contra » ALANUS ANGLicus, Appartus Ius Naturale, D. XL c. 6 BnF ms 3909, fol. 8 va, s.v. a fide: «Set nonne damasus de adulterio est accusatus ut infra ii. Q. vii § cum balaam in fi. (C. II, q. 7, dict. p. c. 41). Item si publicus fenerator esset nunquid accussari posset? posset secundum quosdam de omni notorio, qui large accipiunt peccare in fide, i. (e) contra doctrinam fidei nostre sicut omnis mortaliter peccans dicitur Christum negare ut infra xi. Q. iii. Existimant (C. XI, q. 3, c. 84). Set secundum hoc nullum esset hic pape privilegium. Ideo dicendum quod cum iudicem non habeas superiores inuitus iudicari non potest nisi de crimine hereseos in quo propter criminis enormitatem et comune periculum ecclesie est statutum. Set nunquid alius pape possit legem imponere cum papa canonibus sit solutus et possit eos mutare. Forte ita est in hoc crimine quia ibi quasi per consequentiam revocatur in dubium utrum papa sit. Videtur enim quod si hereticus est caput ecclesie non est. Si vero de alio crimine infamatur et alius velit eum accusare non (=ne) in eo ecclesia scandalizaretur, licet cogi non possit, tamen ammonitus iudice eligere debebit et sube o litigare. Quamvis enim legibus solutus sit secundum leges tamen vivere debet.» J. M. MOYNIHAN, Papal Immunity and Liability in the Writings of the Medieval Canonists, p. 94-101.

31. J. GERSON, An liceat in P. GLORIEUX, Oeuvres complètes, Tournai, 1960-1963, 6, 286 and DU PIN, Opera omnia, Amberes, 1706, II, 305CD : «...non est verum quod papa eo facto quod cadit in haeresim praesertim latentem, sit depositus a papatu, sicut non est verum de aliis episcopis; peccatum haeresis, licet reddat unum praelatum dignum depositione, iuncta pertinacia, non tamen reddit eum depositum eo facto, sed requiritur humana dispositio ». Cf. G. H. M. POSTHUMUS MEYJES, Jean Gerson. Apostole of Unity. His Church Politics and Ecclesiology, Leiden, 1999, p. 174. J. GERSON, Tradidit Jesum, (Gl. 5, 558 ; DU PIN II, 593BC) : « etsi praelatus haereticus dignus est deponi, nihilominus non 
este o facto depositus, sicut aliquis quantumcumque sit dignus episcopari non est eo facto episcopus, nisi per eletionem divinam vel humanam manifestam.» G. H. M. POSTHUMUS MEYJES, op. cit., p. 173.

32. The idea that the theological thought of J. Hus would be a mere copy of of J. Wyclif's thought has been supported openly by the works of J. Loserth written at the end of xIxth century. Through a linguistic study opposing some texts of J. Wyclif and J. Hus, J. Loserth arrived to this wrong conclusion. About these historiographical problems cf. F. ŠMAHEL, Die Hussitische Revolution, Monumenta Histoirae Germaniae, Hanovre, 2002 (3 vol.), vol. I, p. 41. In effect, although the wyclifite influence is undeniable, nowadays the scholars tend to outline Hus' creative and selective apropiation of some theological concepts developed by Wyclif. For a clear example of this attitude cf. H. KAMINSKY, A History of The Husite Revolution, Oregon, 2004 [reedition of the text published in 1967 by University California Press], p. 7-35. About the differences between the thought of J. Hus and of J. Wyclif cf. Dom De Vooght's works : P. DE VOoGHT, « Jean Hus à l'heure de l'œcuménisme », Irénikon, v. 36, 3 (1969) p. 193-313 ; P. DE VOOGHT, « Universitas praedestinatorum et congregatio fidelium dans la l'ecclésiologie de Jean Hus ", Ephemerides Theologicae Lovanienses, v. 32, 3-4 (1956), p. 487-534 ; P. DE Vooght, Husiana, Louvain, 1960 ; P. DE Vooght, Jean Hus au Symposium Husianum Pragense, Istina, Paris, 1965-1966 ; P. DE VooGHT, L'hérésie de Jean Hus, Louvain, 1960. More recently on the same issue cf. B. TÖPFER, «Lex Christi, dominium und kirchliche Hierarchie bei Jan Hus im Vergleich mit John Wyclif» in F. SEIBT. (Hrg.) Jan Hus, zwischen Zeiten, Völkern, Konfessonen, Veröffentlichungen des Collegium Carolinum 85, München, Oldenbourg, 1997, p. 157-166 and E. S. MOLNAR, " Wyclif, Hus and the problem of Authority » en F. SEIBT. (Hrg.) Jan Hus, zwischen Zeiten, Völkern, Konfessonen, op. cit., p. 167-182.

33. Cf. M. WILKS, The problem of Sovereignty in the Later Middle Ages, Cambridge, 1963, p. 516-523.

34. J. GERSON, De auferibilitate, cons. 12 in P. GLORIEUX, op. cit. 3, p. 304-305; DU PIN, op. cit. II, 217D-18C : «Sed utrum haec obedientiae subtractio...valeat per alium quam per ecclesiam vel generale concilium? Forte videtur respondendum negative, praesertim si fiat sermo de substractione generali et auctoritativa, et quae liget omnes de ecclesia in hoc stare; secus est de substractione particulari quoad hos vel illos et quae non fertur autoritative; sed vel doctrinaliter et insinuative, vel necessitatis quadam inductione. " He makes an allusion to the Petit affair: "Quanto magis erronea et damnanda est assertio quod licet unicuique subditorum mox ut aliquis est tyrannus, ipsum viis omnibus fraudulentis et dolosis sine quavis auctoritate vel declaratione iudiciaria morti trahere; praesertim si addat haec assertio quod tyranus ille omnis est, qui non praeest ad utilitatem subditorum. Sed de hac re alibi, de qua viderint assertores.»Cf. G. H. M. POSTHUMUS MEYJES, op. cit. p. 173.

35. N. I. TINTEROFF, "Assemblée conciliaire et liturgie aux conciles de Constance et Bâle", Cristianesimo nella storia, vol. XXVI/2, 2005, p. 395-425 and H. SCHNEIDER, «Die Siegel des Konstanzer Konzils. Ein Beitrag zur Geschichte der spätmittelalterlichen Reformkonzile », Annuarium Historiae Conciliorum, 10, 1, 1978, p. 310-345.

\section{INDEX}

Mots-clés: Haec sancta, Inquisitorial process, Conciliarism, Heresy 


\section{AUTHOR}

\section{SEBASTIÁN PROVVIDENTE}

Université de Buenos Aires 